Jurnal Kesehatan

Volume 9, Nomor 2, Agustus 2018

ISSN 2086-7751 (Print), ISSN 2548-5695 (Online)

http://ejurnal.poltekkes-tjk.ac.id/index.php/JK

\title{
Tingkat Hygiene dan Kandungan Escherichia coli pada Air Tebu yang Dijual Sekitar Kota Medan
}

\author{
Benny M.P.Simanjuntak ${ }^{1}$, Wirsal Hasan ${ }^{2}$, Evi Naria ${ }^{3}$ \\ ${ }^{1,2,3}$ Fakultas Kesehatan Masyarakat, Universitas Sumatera Utara, Indonesia \\ Email: haripinsinaga@yahoo.com
}

\begin{abstract}
Hygiene and Escherichia coli Levels on Cane Water which is Sold Around Medan City. WHO (World Health Organization) mentions that water quality is biologically determined by the presence of E. coli bacteria. The content of E.Coli bacteria allowed in drinking water is 0 per $100 \mathrm{ml}$ of sample. Sugar cane juice is one of the most E.Coli contaminated beverages. E. coli can cause disease associated with digestion such as diarrhea and including urinary tract infections, gastroenteritis, meningitis, peritonitis, and wound infections. The purpose of this study was to analyze the relationship of sanitary hygiene of vendors and environment with Escherichia coli content in sugar cane juice. The research was an analytic research using cross-sectional design approach. The sample of this study was 30 sugar cane vendors around Medan city. Data analysis using Pearson and linear regression test. Measurement aspects were sugar cane processing, transportation, sugar cane storage, sugarcane transportation and serving of sugar cane juice. The results showed a significant relationship between processing $(\mathrm{p}=0,00)$, location $(\mathrm{p}=0,02)$, transportation $(\mathrm{p}=0,00)$ and serving $(\mathrm{p}=0,00)$ with the present of E.Coli on sugarcane. It is suggested to the government conducting supervision and educates the sugarcane vendors to prepare their products based on regulation of the District Health Office.
\end{abstract}

Keywords: Sugarcane, E. Coli, Hygiene

\begin{abstract}
Abstrak: Tingkat Hygiene dan Kandungan Escherichia coli pada Air Tebu yang Dijual Sekitar Kota Medan. WHO (World Health Organization) menentukan kualitas air secara biologis ditentukan oleh kehadiran bakteri E. Coli. Kandungan bakteri E.Coli yang diperbolehkan dalam air minum maksimum adalah 0 per $100 \mathrm{ml}$ sampel. Air tebu adalah salah satu jenis minuman yang dapat tercemar. E.Coli dapat menyebabkan penyakit yang berkaitan dengan pencernaan seperti diare termasuk infeksi saluran kemih, gastroenteritis, meningitis, peritonitis, dan infeksi luka. Tujuan penelitian ini adalah untuk menganalisis hubungan hygiene sanitasi lingkungan penjualan dengan kandungan Escherichia coli pada air tebu. Jenis penelitian ini adalah penelitian analitik menggunakan pendekatan desain cross sectional. Populasi dalam penelitian ini sebanyak 30 penjual minuman sari tebu yang berjualan di sekitar kota Medan. Analisis data menggunakan uji Pearson dan uji regresi linier. Aspek pengukuran dilakukan terhadap pemilihan tebu, pengolahan tebu, penyimpanan tebu, pengangkutan tebu dan penyajian air tebu. Hasil penelitian menunjukkan adanya hubungan yang signifikan antara pengolahan $(p=0,00)$, penyimpanan $(p=0,02)$, pengangkutan $(p=0,00)$ dan penyajian $(p=0,00)$ dengan keberadaan E.coli pada minuman air tebu. Variabel yang paling dominan berhubungan adalah adalah penyajian air tebu. Konsumen air tebu di Kota Medan mempunyai resiko tinggi terhadap penyakit diare. Pemerintah melalui Dinas Kesehatan harus aktif mengawasi dan melakukan penyuluhan serta merencanakan pelatihan HCCP kepada penjual air tebu.
\end{abstract}

Kata kunci: Air Tebu, E.Coli, Hygiene

WHO (World Health Organization)
menentukan kualitas air secara biologis
ditentukan oleh kehadiran bakteri E.Coli.
Kandungan bakteri E.Coli yang diperbolehkan
dalam air minum maksimum adalah 0 per $100 \mathrm{ml}$
sampel (Depkes RI, 2010). Keberadaan
Escherichia Coli yang melebihi ambang batas
menunjukkan praktek sanitasi lingkungan yang
buruk sedangkan Staphylococcus aureus

mengidentifikasi praktek hygiene yang kurang (Wijaya, 2009).

E.Coli dapat menyebabkan penyakit pada manusia terutama penyakit yang berkaitan dengan pencernaan seperti diare. Penyakitpenyakit lain yang disebabkan E.Coli yaitu infeksi saluran kemih, gastroenteritis, meningitis, peritronitis, dan infeksi luka (Brooker, 2009). 
Air tebu adalah salah satu jenis minuman yang dapat tercemar. Hal ini kemungkinan sumber bakteri pencemar adalah lingkungan kebersihan pasar dan proses pengolahan air tebu. Hasil penelitian Munthe (2006) menemukan kandungan E.Coli dalam air tebu di pasar kota Medan tidak memenuhi persyaratan kualitas bakteriologis air minum. Dari 16 sampel, semua sampel (100\%) mengandung E.coli.

Air tebu merupakan minuman jajanan yang dijual tanpa kemasan khusus, diproduksi di tempat penjualannya sehingga sulit dilakukan pengawasan terhadap mutunya. Saat ini di kota Medan banyak ditemukan pedagang kaki lima menjual minuman air tebu (BPS Kota Medan, 2016). Minuman air tebu biasanya dijual dengan menggunakan gerobak lengkap dengan mesin khusus pemeras air tebu yang bisa disajikan dalam gelas plastik ataupun kantong-kantong plastik.

Berdasarkan masalah di atas penulis ingin mengetahui kualitas air tebu secara bakteriologis khususnya kandungan bakteri Escherichia Coli.

Tujuan penelitian ini adalah untuk mengetahui tingkat hygiene sanitasi lingkungan penjualan dengan kandungan Escherichia coli pada air tebu.

\section{METODE}

Jenis penelitian menggunakan pendekatan desain cross sectional. Populasi penelitian sebanyak 30 penjual minuman sari tebu dan seluruhnya dijadikan sampel yang berada di sekitar Kota Medan. Waktu penelitian mulai dari bulan Agustus-Oktober 2015.

Variabel dependent adalah pengolahan, lokasi, pengangkutan dan penyajian. Pengolahan air tebu mencakup cara mengupas, memotong, menggiling dan menyaring.

Sebanyak 30 sampel air tebu yang dipilih secara Purposive dengan kriteria berjualan di lima kecamatan Kota Medan, lama berjualan lebih dari 2 tahun dan menggunakan jenis tebuh merah. Sampel diperiksa di Laboratorium Balai Teknik Kesehatan Lingkungan dan Pengendalian Penyakit Kelas I Medan.

Metode pengujian air tebu menggunakan APHA9221B.22nded2012. Selanjutnya dilakukan pemeriksaan Most Probale Number (MPN) terhadap air tebu yang telah disiapkan pada tabung ganda: $3 \times 10 \mathrm{ml}, 3 \times 1 \mathrm{ml}$ dan $3 \times 0,1 \mathrm{ml}$. Kemudian pemeriksaan tabung dilakukan dengan test perkiraan (Presumtive test) dan Test Penegasan (confirmative test). Media yang digunakan untuk test perkiraan adalah Lactose Broth Single and Double Strain sedangkan untuk test penegasan menggunakan Briliant Green Lactose Broth 2\%. Pembacaan hasil test penegasan dengan menghitung jumlah tabung yang menunjukkan adanya gas pada tabung dengan suhu $37^{\circ} \mathrm{C}$ dan suhu $44^{\circ} \mathrm{C}$ (BPOM, 2008; Lestari, 2013).

Peneliti juga melakukan pengamatan terhadap perilaku penjual selama berjulan meliputi higiene pengelola, persiapan alat dan lingkungan jualan. Pengamatan menggunakan formulir observasi.

Analisis data dilakukan dengan menggunakan uji Pearson dan uji $r$ regresi linier. Aspek pengukuran dilakukan dengan melihat gambaran hygiene sanitasi air tebu yang dijual di beberapa kecamatan di kota Medan meliputi pengolahan, lokasi penjualan, pengangkutan dan penyajian air tebu (Setiadi, 2000).

\section{HASIL}

Tabel 1. Karakteristik Penjual Air Tebu

\begin{tabular}{lrc}
\hline \multicolumn{1}{c}{ Karakteristik } & n & \% \\
\hline Pendidikan & & \\
\hline SD & 5 & 16,7 \\
SMP & 11 & 36,7 \\
SMA & 14 & 46,7 \\
\hline Jenis Kelamin & & \\
\hline Laki-laki & 20 & 66,7 \\
Perempuan & 10 & 33,3 \\
\hline Umur (tahun) & & \\
\hline $20-25$ & 8 & 26,7 \\
$26-30$ & 6 & 20,0 \\
$31-35$ & 13 & 43,3 \\
$>35$ & 3 & 10,0 \\
\hline Lama berjualan (tahun) & \\
\hline 5 & 12 & 40,0 \\
6-10 & 10 & 33,3 \\
$>10$ & 8 & 26,7 \\
\hline
\end{tabular}

Tabel 1 di atas menjelaskan bahwa mayoritas penjual air tebu adalah tamatan SMA (46,7\%), laki-laki $(66,7 \%)$, kelompok usia terbesar $31-35$ tahun $(43,3 \%)$ dan 8 orang $(26,7 \%)$ sudah berjualan lebih dari 10 tahun.

Tabel 2. Kandungan E.Coli pada AirTebu

\begin{tabular}{lccccc}
\hline Variabel & n & Min & Max & Mean & SD \\
\hline E.Coli & 30 & 1,50 & 1900,00 & 529,00 & 762,17 \\
\hline
\end{tabular}

Dari 30 sampel air tebu ternyata tidak satu pun yang bebas dari E.Coli. seperti terlihat pada tabel 2, rata-rata air tebu mengandung E.Coli $529,00( \pm 762,17) \mathrm{MPN} / 100 \mathrm{ml}$. 
Tabel 3. Hasil uji Korelasi Pearson terhadap Keberadaan E.Coli Air Tebu

\begin{tabular}{lll}
\hline \multicolumn{1}{c}{ Variabel } & $\begin{array}{l}\text { Corelation } \\
\text { Coefficient }\end{array}$ & p-value \\
\hline Pengolahan & $-0,561$ & 0,001 \\
Penyimpanan & $-0,412$ & 0,024 \\
Pengangkutan & $-0,573$ & 0,001 \\
Penyajian & $-0,347$ & 0,060 \\
\hline
\end{tabular}

Dari empat variabel yang diuji, ternyata tiga variabel memiliki pengaruh yang signifikan terhadap keberadaan E. Coli pada air tebu $(p<0,05)$. Variabel penyajian tidak berpengaruh terhadap E.coli. Seperti terlihat pada Tabel 3, hasil Corelation Coefficient menunjukkan nilai negatif pada setiap variabel. Angka ini menyimpulkan bahwa semakin baik pengolahan, penyimpanan, pengangkutan dan penyajian pada air tebu maka resiko adanya bakteri E.Coli semakin kecil.

Tabel 4. Hasil Analisis Determinasi

\begin{tabular}{ccc}
\hline $\mathbf{R}^{2}$ & $\mathbf{F}$ & $\boldsymbol{p}$ value \\
\hline 0,607 & 0,000 & 0,000 \\
\hline
\end{tabular}

Tabel di atas menjelaskan hasil uji serempak menyimpulkan nilai $\mathrm{F}$ dan $p$-value $<0,05$, artinya ada pengaruh variabel pengolahan, penyimpanan, pengangkutan dan penyajian terhadap E.Coli pada minuman air tebu. Sedangkan nilai regresi $\left(\mathrm{R}^{2}\right)=0,607$ menunjukkan bahwa variabel pengolahan, penyimpanan, pengangkutan dan penyajian mampu menjelaskan variasi pada E.Coli sebesar $60,70 \%$, selebihnya $39,30 \%$ dipengaruhi atau dijelaskan oleh variabel lain yang tidak termasuk dalam model regresi yang digunakan.

Tabel 5. Pengaruh Pengolahan dan Penyajian
\begin{tabular}{lcc} 
Minuman Air Tebu & \\
\hline \multicolumn{1}{c}{ Variabel } & B & Sig \\
\hline Konstanta & 2.779 .317 & 0,000 \\
Pengolahan & -158.600 & 0,021 \\
Penyajian & -464.985 & 0,000 \\
\hline
\end{tabular}

Hasil uji regresi linear ganda terhadap variabel pengolahan dan penyajian mendapatkan persamaan garis regresi:

$$
Y=2.779 .317-158,600 X_{1}-464,985 X_{2} \text {, }
$$

Untuk variabel pengolahan diperoleh nilai $p=0,021<0,05$, berarti ada pengaruh variabel pengolahan terhadap E.Coli sedangkan nilai koefisien $b_{1}=-158,600$, artinya jika nilai variabel pengolahan mengalami penurunan sebesar satu poin, sementara hal-hal lainnya bersifat tetap, maka adanya E.coli (Y) akan menurun sebesar 158,600 poin.

Untuk variabel penyajian diperoleh nilai $p=0,000<0,05$, artinya ada pengaruh penyajian. Nilai koefisien $b_{1}=-0,464,985$, artinya apabila nilai variabel penyajian mengalami penurunan sebesar satu poin, sementara hal-hal lainnya bersifat tetap, maka adanya E.Coli akan menurun sebesar -0,464,985 poin (Lihat Tabel 5).

\section{PEMBAHASAN}

Hasil penelitian menyimpulkan bahwa terdapat hubungan yang signifikan antara pengolahan minuman air tebu dengan kandungan E.coli pada sari air tebu. Faktor penyimpanan, pengolahan dan pengangkutan sangat berpengaruh terhadap munculnya E.coli. Selain karena air tebu tidak tertutup rapat, penggunaan es batu dan air isi ulang depot yang digunakan oleh penjual air tebu menyebabkan kandung E.Coli mencapai 529,00( $\pm 762,17) \mathrm{MPN} / 100 \mathrm{ml}$. Hasil pengamatan peneliti, semua penjual menggunakan air isi ulang depot dan es batu.

Umumnya air tebu yang sudah mengandung es batu disimpan dalam termos, tetapi suhunya tidak stabil. Menurut, Krishnakumar, dkk. (2013) suhu yang tepat untuk menyimpan batang tebu adalah $10^{\circ}-30^{\circ} \mathrm{C}$ Tetapi jika lebih dari 4 hari pada batang tebu akan tumbuh jamur. Ketika sudah diperas menjadi air tebu suhu yang tepat adalah $5^{0}-30^{\circ} \mathrm{C}$. Suhu $10^{\circ} \mathrm{C}$ merupakan suhu yang ideal untuk mempertahan kwalitas air tebu hingga 9 hari.

Perilaku penjual air tebu dalam mengolah dan menyajikan air tebu di gelas menggunakan air pencucian gelas kurang higienis dan suka menggaruk kepala dan hidung pada saat berjualan. Ternyata perilaku penjual air sari tebu seperti hasil penelitian ini juga ditemukan di Palembang, Kota Denpasar dan Tembalang (Agustina F, dkk (2009); Antarini N, dkk (2011); ( Lestari D.P., dkk, 2015).

Penelitian Hidayat (1995) di dua propinsi yaitu Jawa Tengah dan DIY Yogyakarta menemukan bahwa tempat cuci gelas atau piring yang menggunakan hanya satu ember untuk mencuci alat-alat makan yang kotor untuk digunakan seharian. Anjuran Departemen Kesehatan RI (2004), peralatan yang terbuat dari kayu dan plastik harus dibersihkan sebelum digunakan, dicuci dengan sabun dibilas sampai bersih hingga tidak berbau. Sistem pengolahan dan penyajian yang tidak higienis menyebabkan mudah tercemar dengan mikroba E.Coli dan jamur (Lestari, 2013). 
Pengolahan kulit tebu tidak dikupas bersih dan alat penggiling kurang bersih menyebabkan juga faktor penyebab mudahnya air tebu terkontamisasi dengan mikrob E.coli. Mesin penggiling air tebu yang tidak langsung dibersihkan dan digunakan tanpa proses pencucian juga ditemukan di Palembang (Antarini, dkk, 2011).

Melihat kondisi seperti dikhawatirkan konsumen air tebu akan mudah menderita penyakit diare. Jika Dinas Kesehatan tidak melakukan tindakan yang cepat melakukan penyuluhan kepada penjual air tebu maka masyarakat pencinta air tebu di Kota Medan terancam mengalami penyakit bersumber dari makanan (food borne microbial disease) bahkan outbreak diarrhea.

\section{DAFTAR PUSTAKA}

Agustina, F., Pambayun, R., \& Febry, F. 2009. Higiene dan sanitasi pada pedagang makanan jajanan tradisional di lingkungan sekolah dasar di Kelurahan Demang Lebar Daun Palembang tahun 2009. Jurnal Publikasi Ilmiah Fakultas Kesehatan Masyarakat Universitas Sriwijaya.

Antarini, N., dkk. 2011. Keamanan Pangan Pada Es Sari Tebu yang dijual di Kota Denpasar. Jurnal Ilmu Gizi Vol. 3, No. 1. Februari 2012.

Badan Pusat Statistik, 2016. Kota Medan Dalam Angka. Medan.

BPOM. 2008. Pengujian Mikrobiologi Pangan. Jakarta: Pusat Pengujian Obat dan Makanan. Badan Pengawasan Obat dan Makanan Republik Indonesia

Brooker, 2009. Brooker, R. J. 2005. Genetic: Analysis and Principle. McGraw Hill Companies, Inc., Boston : xxii + $842 \mathrm{hlm}$.

Depkes RI. 2010. Keputusan Menteri Kesehatan RI Nomor 492 tentang Persyaratan Kualitas Air Minum. Jakarta.

Hidayat, E. B. 1995. Anatomi Tumbuhan Berbiji. Cetakan ke-1. Bandung: Institut Teknologi Bandung.

Krishnakumar T, dkk. 2013. Effect of delayed extraction and storage on quality of

\section{SIMPULAN}

Hubungan yang signifikan antara pengolahan batang tebu, penyimpanan, pengangkutan dan penyajian air minuman sari tebu dengan kehadiran mikroba E. coli.

\section{SARAN}

Pemerintah melalui Dinas Kesehatan Kota Medan supaya melakukan pengawasan dan penyuluhan rutin terhadap penjual air minum sari tebu. Pelatihan HCCP juga perlu dipertimbangkan untuk semua penjamah makanan agar mereka sadar tentang pentingnya kebersihan pada proses pengolahan makanan agar konsumen terhindar dari penyakit diare.

sugarcane juice. African Journal of Agricultural Research. Vol.8 (10), pp. 930935.

Lestari I.A. 2013. Pembuatan Label Cerdas Pendeteksi Echerechia Coli. [Skripsi]. Bogor: Fakultas Teknologi Pertanian Bogor, Institut Pertanian Bogor.

Lestari, D.P, dkk. 2015. Hubungan Higiene Penjamah dengan Keberadaan Bakteri Escherichia coli pada Minuman Jus Buah di Tembalang. Jurnal Kesehatan Lingkungan Indonesia, Vol. 14.

Munthe. 2006. Pemeriksaan Escherichia coli pada Air Tebu yang Dijual di Beberapa Pasar Tradisional di Kota Medan Tahun 2006. [Skripsi]. Medan: Fakultas Kesehatan Masyarakat Universitas Sumatera Utara.

Setiadi. 2000. Konsep dan Penulisan Riset Keperawatan. Yogyakarta: Graha Ilmu.

Wijaya, Rika. 2009. Penerapan Peraturan dan Praktek Keamanan Pangan Jajanan Anak Sekolah di Sekolah Dasar Kota Dan Kabupaten Bogor. [Skripsi]. Bogor: Departemen Gizi Masyarakat, Fakultas Ekologi Manusia, Institut Pertanian Bogor. 